Matgorzata Osowiecka, Izabella Gacka

SWPS Uniwersytet Humanistycznospołeczny

Wydział Zamiejscowy w Sopocie

\title{
Artysta bez skrzydeł? Regulacja emocji poprzez doświadczenia estetyczne
}

Twórczość bywa rekompensatą, choć czasem bardzo utajoną, z bardzo skrywanych braków i utrat płynącą jak z podziemnego źródła.

Maria Dąbrowska

\section{Wprowadzenie}

Inspiracją do sformułowania tytułu artykułu był plakat zatytułowany "Człowiek bez skrzydeł” zaprezentowany podczas warszawskiego pokazu z kolekcji Galerii Plakatu Piotra Dąbrowskiego. Zbiór posterów obejmował najważniejsze, ale jednocześnie najbardziej dramatyczne momenty historii powojennej sztuki. Jeden z nich przedstawiał człowieka zniewolonego, metaforycznie pozbawionego skrzydeł. Nasuwa to analogię do człowieka zależnego od stosowanej przez niego strategii regulacji emocji, która może mieć charakter adaptacyjny bądź nieadaptacyjny. Określenie bohatera posteru mianem artysty jest o tyle adekwatne, że to właśnie artyści są grupą targaną przez trudne, nieraz niezrozumiałe emocje, które próbują rozładować przez tworzenie. Tytułowym artystą może być jednak każdy, a twórczość - uniwersalnym sposobem radzenia sobie z emocjami. Takie rozumienie dzieła Dąbrowskiego rodzi pytanie: w jaki sposób szeroko rozumiana twórczość może wpływać na regulację emocji?

\section{Regulacja emocji}

Regulacja emocji może mieć charakter osobowościowy lub może być kształtowana przez indywidualną jednostkę. W pierwszym przypadku jest to związane z pewnym zapleczem genetycznym (Soroko 2007). W drugim, prawdopodobnie najbardziej skorelowanym z dobrostanem człowieka, jest wola samej jednostki. David G. Myers (2000) pisze, że celem wielu badaczy jest sprawdzenie, co prowadzi do szczęścia. Większość ludzi jest szczęśliwa tylko w umiarkowanym 
stopniu i szczęście jest dla nich stanem, który mogą sobie jedynie wyobrażać. Randy J. Larsen (2000) zauważa, że ludzie angażują się w różnego rodzaju działalność, która ma służyć redukcji nieprzyjemnych subiektywnie stanów emocjonalnych, na przykład smutku czy lęku. Chociaż różnimy się między sobą w progu reaktywności emocjonalnej oraz w sposobie regulacji emocji, wszyscy jesteśmy podobni w tym, że dążymy do dobrego samopoczucia. Redukcja negatywnego afektu jest uniwersalnym celem każdego człowieka (Larsen 2000). Na przykład angażowanie się w różne sposoby regulacji strachu przedegzaminacyjnego skutecznie redukuje tę emocję - w porównaniu z brakiem ich podejmowania - i prowadzi do lepszych rezultatów w teście (Shcherbatykh 2000).

Termin „regulacja emocji” można stosować w dwóch przypadkach. W pierwszym emocje są regulatorami procesów poznawczych (Marszał-Wiśniewska, Fajkowska 2010). Oznacza to, że pod ich wpływem zmienia się zakres uwagi albo pojemność pamięci. W drugim przypadku to emocje są regulowane. Dzieje się tak, kiedy monitorujemy nasze emocje i je modyfikujemy, stosując różne strategie: poznawcze, behawioralne, społeczne, biologiczne (Marszał-Wiśniewska, Fajkowska 2010). Strategią poznawczą będzie na przykład pozytywne przeformułowanie sytuacji, strategią behawioralną słuchanie muzyki, społeczną - spotkanie z przyjaciółmi, a biologiczną - sen albo picie znacznej ilości alkoholu celem poprawy nastroju. Regulacja emocji sprowadza się najczęściej do procesów, dzięki którym jesteśmy w stanie monitorować, dokonywać ewaluacji, zmiany intensywności oraz czasu trwania naszych emocji (Gross 1999). W tym artykule najbardziej interesującym nas aspektem regulacji emocji jest ich świadoma regulacja przy pomocy wybierania konkretnych form aktywności (zwłaszcza ekspresywnego pisania) oraz regulacja osobowościowa, która może prowadzić do preferowania pewnych zachowań bardziej niż innych.

\section{Związek arteterapii z regulacją emocji}

Arteterapia - według Amerykańskiego Stowarzyszenia Arteterapii (American Art Therapy Association 2015) - jest profesją z dziedziny zdrowia psychicznego. Klienci wspomagani przez arteterapeutów - korzystając z artystycznych środków wyrazu - dążą między innymi do zrozumienia swoich uczuć, pogodzenia emocjonalnych konfliktów, rozwijania samoświadomości, a także uczą się zarządzać zachowaniem i uzależnieniami, rozwijają zdolności interpersonalne, poprawiają orientację w rzeczywistości, redukują lęki i zwiększają poczucie własnej wartości. Trening arteterapeutyczny korzysta ze sztuk plastycznych (między innymi rysowania, malowania, rzeźbienia) oraz pisarskich, wzbudzając proces twórczy, oraz z wiedzy psychologicznej na temat rozwoju człowieka, technik terapeutycznych, a także różnych teorii psychoterapeutycznych. Współczesna arteterapia ma szerokie zastosowanie w różnorodnych miejscach, włączając szpitale, obiekty psychiatryczne i rehabilitacyjne, obiekty Wellness, instytucje sądowe, szkoły, centra kryzysowe, społeczności seniorów, prywatne praktyki. Arteterapeuci na indywidualnych 
i grupowych sesjach wywołują u klientów proces twórczy, który ma im pomóc osiągnąć fizyczny, psychiczny i emocjonalny dobrostan (American Art Therapy Association 2015). Podczas sesji terapeutycznej „językiem” spotkania są wytwory artystyczne stworzone z dostępnych materiałów i kolorów, które wybierają klienci (Corem, Snir, Regev 2015). Ułatwia im to przekazywanie uczuć w sposób pozawerbalny. Dialog przeprowadzony przy użyciu innych środków przekazu niż słowa prowokuje zetknięcie z doświadczanymi, ale nierzadko głęboko skrywanymi, uczuciami. Bardzo ważna jest też obecność arteterapeuty, który stwarza atmosferę zaufania i ułatwia klientom przejście przez proces samoeksploracji (Corem, Snir, Regev 2015).

\section{Regulacja emocji przez doświadczenia estetyczne}

Tworzenie sztuki jest rozumiane szeroko jako działalność podejmowana w celu regulacji nastroju (Goldstein, Tamir, Winner 2013). Większość artystów jest przekonana (a na pewno ma chociaż takie przeczucie), że tworzy, aby zapewnić sobie emocjonalny dobrobyt. Warte uwagi są również powody tworzenia sztuki w trudnych emocjonalnie warunkach (więźniowie obozów koncentracyjnych, więźniowie polityczni).

Larsen twierdzi, że tworzenie dzieła sztuki, niezależnie od jego formy (na przykład kreślenie na kartce papieru, wydawanie dźwięków), wpływa pozytywnie na polepszenie dobrostanu twórcy (Larsen 2000). Jennifer E. Drake i Ellen Winner w serii badań przeprowadzonych na grupie małych dzieci dowiodły, że rysowanie pomaga im radzić sobie z negatywnymi emocjami (Drake, Winner 2013). Według autorek radość płynąca z czynności rysowania jest konkurencyjna dla smutku czy rozczarowania i odwraca uwagę od tych negatywnych emocji niezależnie od umiejętności autora. Działalność musi być jednak - jak piszą autorki - aktywna. Samo obserwowanie czyjegoś procesu twórczego nie działa na nas w żaden istotny sposób. Natomiast Thalia R. Goldstein, Maya Tamir i Ellen Winner przeprowadzili badanie z udziałem adolescentów. Dowiedli, że zaangażowanie w wyrażanie emocji za pośrednictwem aktorstwa różnicowało badanych pod względem skłonności do ukrywania negatywnych emocji (Goldstein, Tamir, Winner 2013). Interesująca jest także tendencja osób pozostających w smutnym nastroju do słuchania piosenek o takim właśnie zabarwieniu emocjonalnym. Badaczki Annemieke J.M. Van den Tol i Jane Edwards (Van den Tol, Edwards 2015) sprawdziły, co ludzie smutni chcieliby w ten sposób osiągnąć, i opisały kilka powodów takiego działania. Pierwszym jest identyfikacja z emocjami płynącymi z danej piosenki, która pozwala słuchaczom na powtórne ich przeżycie i dokonanie „reinterpretacji poznawczej”, czyli spojrzenia na bodziec emocjonalny z innej strony. Kolejnym powodem jest połączenie się z przekazem danej piosenki, który motywuje do działania. Wysoka wartość estetyczna, jako trzecia przyczyna, przyciąga uwagę słuchaczy. Według autorek prowadzi to jednak do nieadaptacyjnej regulacji emocji, jaką jest odwracanie uwagi od problemu. Wreszcie wspomnienia przeszłych wydarzeń związanych z daną 
piosenką pozwalają powrócić do dawnych czasów i przeżyć je na nowo, a także zobaczyć w innym świetle (Van den Tol, Edwards 2015). Udowodniono także, że hip-hop może pomóc w walce z depresją, a nawet schizofrenią (Sule, Inkster 2014). Teksty takich piosenek często obrazują wiele trudności życia w ubogich dzielnicach, na przykład uzależnienia i doświadczanie przemocy. Zdaniem Akeem Sule i Becky Inkster wykonawcy, tworząc takie utwory, radzą sobie z problemami, zaś słuchaczom dają nadzieję na lepszą przyszłość (Sule, Inkster 2014).

\section{Ekspresywne pisanie}

Pisanie może być rodzajem terapii (formalnej bądź podejmowanej samodzielnie w domu) polegającej na ekspresji emocji, jak twierdzą Joshua M. Smyth, Deborah Nazarian i Danielle Arigo (Smyth, Nazarian, Arigo 2008). Programy terapeutyczne, niezależnie od formy czy orientacji teoretycznej terapeuty, kładą nacisk na ujawnianie, identyfikowanie oraz nazywanie trudnych emocji (Smyth, Helm 2003). Rozmaite zahamowania społeczne, wstyd oraz nieumiejętność wyrażania emocji $\mathrm{w}$ inny sposób daje pisaniu przewagę, ponieważ w realizacji celów terapii nie ma konieczności wypowiadania się na głos.

W badaniach nad wpływem ekspresywnego pisania badacze sprawdzają, jak pisanie o własnych emocjach wpływa na poprawę dobrostanu osób badanych. Badani są dzieleni zazwyczaj na dwie grupy. Jedna grupa pisze na temat swoich trudnych emocji, zaś druga opisuje zwykły dzień w pracy albo plany na nadchodzący tydzień (Pennebaker, Beall 1986). Zazwyczaj osoby badane piszą o trudnych przeżyciach przez około piętnaście-dwadzieścia minut przez od trzech do pięciu sesji. Kolejne dziesięć minut powinno zająć badanym dojście do siebie po tej czynności. Ustalane maksimum to najczęściej dwadzieścia minut, aby nie wywoływać u osoby badanej obciążenia i poczucia, że nie jest w stanie zrealizować tego zadania. Sesje pisania powinny odbywać się w miejscu cichym, spokojnym i komfortowym. Jeśli sesje są częścią psychoterapii, odbywają się zazwyczaj pomiędzy spotkaniami z terapeutą. W instrukcji do zadania zachęca się uczestników do pisania o głębokich uczuciach bez obawy o poprawność gramatyczną czy ortograficzną. Temat jest najczęściej wybierany przez samą osobę i może dotyczyć zawsze tego samego bądź za każdym razem innego problemu (Baikie, Wilhelm 2005). Ważny jest brak oceny pisanych treści, co pozwala osobie na całkowitą szczerość. Istotna jest również pełna dowolność nie tylko dotycząca treści, ale również nadanej struktury oraz długości tekstu. Chociaż często osoby badane raportują przeżywanie smutku bądź innych negatywnych emocji po sesjach pisania, zazwyczaj uważają tę formę terapii za użyteczną, wartościową i znaczącą (Pennebaker 1997).

W licznych badaniach dowiedziono, że ekspresywne pisanie wywiera rzeczywisty wpływ na poprawę dobrostanu, między innymi stanu zdrowia i procesu efektywnego leczenia (Davison, Pennebaker 1997). Kathryn P. Davison i James W. Pennebaker stwierdzili, że grupy osób badanych cierpiących na choroby przewlekłe - w tym raka sutka, raka gruczołu krokowego, cukrzycę, choroby serca, 
zapalenie stawów i zespół przewlekłego zmęczenia - różniły się od osób, które nie miały okazji ekspresywnie pisać o swoich trudnych przeżyciach w stylach komunikacji (osoby te były bardziej otwarte na innych ludzi) (Davison, Pennebaker 1997). Badania przeprowadzone wśród małżonków ofiar różnych zamachów pokazują, że ekspresywne pisanie pomagało im szybciej poradzić sobie z żałobą. Osoby te doświadczały również mniej problemów zdrowotnych (Pennebaker, O’Heeron 1984). Ogółem ekspresywne pisanie przynosi pozytywne rezultaty osobom w nie zaangażowanych zarówno na płaszczyźnie zdrowotnej (na przykład lepsze funkcjonowanie układu immunologicznego, mniejsze ciśnienie tętnicze, wydajniejsza praca serca i wątroby, lepszy nastrój, niższy poziom stresu), jak i społecznej (między innymi wyższe oceny na studiach, mniejsza absencja w pracy, lepsze wyniki w sporcie oraz zmiana zachowania na bardziej społecznie akceptowalne) (Pennebaker, Graybeal 2001).

Dlaczego ekspresywne pisanie jest tak skuteczne? Przytacza się w tym kontekście kilka hipotez, jednak wszystkie sprowadzają się w zasadzie do ekspresji bądź porządkowania emocji. Wśród najważniejszych możliwych wyjaśnień Karen

A. Baikie i Kay Wilhelm podają następujące (Baikie, Wilhelm 2005):

- funkcja katarktyczna: uwolnienie emocji;

- funkcja kontaktu: konfrontacja z wcześniej ukrywanymi emocjami, rozładowanie napięcia;

- funkcja narracyjna: ujęcie trudnych doświadczeń, emocji w spójną historię pomaga je uporządkować;

- funkcja powielenia doświadczenia: przywołanie negatywnych doświadczeń w nowym kontekście, co pozwala zobaczyć je z innej strony.

Wymienione wyjaśnienia mogą wnosić wkład do ostatecznego wpływu ekspresyjnego pisania na dobrostan. Da się równocześnie zauważyć, że każda z tych funkcji może powodować zmiany w ogólnej kondycji człowieka - nie tylko w sferze jego emocji i dobrostanu. Znaczenie mogą tutaj mieć zwłaszcza wymienione już relacje społeczne oraz funkcjonowanie poznawcze, na przykład pamięć oraz twórcze myślenie.

Ekspresywne pisanie wpływa pozytywnie na wyniki akademickie (Pennebaker, Francis 1996) oraz poprawia sprawność pamięci roboczej (Klein, Boals 2001). John F. Disinger dowiódł, że pisanie poprawia myślenie dywergencyjne: czynność ta obniża odpowiedź jądra migdałowatego na negatywne emocje i poszerza zakres uwagi (Disinger 1990). Ekspresyjne pisanie uwalnia od emocji, które mogą być dystraktorami dla aktualnie wykonywanych czynności. Gerardo Beilock i Sian L. Ramirez twierdzą, że opisanie własnych emocji sprawia, iż nie „zalegają" one długo, a tym samym nie decydują o wyniku wykonywanego zadania (Ramirez, Beilock 2011). Ma to znaczenie zwłaszcza, jeśli emocje są związane z wykonywanym zadaniem. 


\section{Zakończenie}

Podsumowując, nie tylko artyści mogą korzystać z dobroczynnego wpływu tworzenia sztuki na dobrostan i efektywność działania. Badania prowadzone na osobach niezajmujących się zawodowo sztuką zgodnie pokazują jej pozytywne działanie na między innymi nastrój i emocje, a co za tym idzie - wyniki akademickie, funkcjonowanie społeczne, poznawcze oraz twórczość. Sposób regulacji emocji poprzez tworzenie nie jest nową formą terapii, zaś programy terapeutyczne i edukacyjne, które wykorzystywałyby tworzenie jako element programu działania danej placówki, są wciąż niepopularne. Istnieją również nadal znaczne kontrowersje dotyczące tego, jak duży nacisk szkoły powinny kłaść na sztukę w programie nauczania (Drake, Winner 2013).

Badania empiryczne prowadzone na jednolitych, reprezentacyjnych próbach, pokazujące wpływ tworzenia - zwłaszcza ekspresyjnego pisania - na wykonywanie zadań poznawczych i inne intrapsychiczne procesy mają charakter wstępny. Klasyczna metoda pisania o emocjach polega na długofalowym procesie opisywania negatywnych przeżyć. Kwestia krótkofalowego wpływu pisania ekspresywnego na funkcje poznawcze pozostaje w sferze planów badawczych. Pojawiają się również pytania, czy skłonność osobowościowa do regulacji emocji w określony sposób (na przykład poprzez obniżanie lub podwyższanie nastroju, ruminowanie) ma znaczenie w kontekście wpływu tworzenia, zwłaszcza ekspresywnego pisania, na funkcjonowanie człowieka, między innymi wykonanie zadania poznawczego.

\section{Literatura:}

American Art Therapy Association, 2015, http://arttherapy.org/aata-aboutus/ [dostęp: 15.08.2015].

Baikie K.A., Wilhelm K., 2005, Emotional and physical health benefits of expressive writing, ",Advances in Psychiatric Treatment" Vol. 11, Iss. 5.

Corem S., Snir S., Regev D., 2015, Patients' attachment to therapists in art therapy simulation and their reactions to the experience of using art materials, "The Arts in Psychoterapy" Vol. 45.

Davison K.P., Pennebaker J.W., 1997, Virtual narratives: illness representations in online support groups [w:] Perceptions of health and illness: current research and applications, eds. K.J. Petrie, J.A. Weinman, Amsterdam: Harwood Academic Publishers.

Disinger J.F., 1990, Teaching Creative Thinking through Environmental Education, „ERIC/SMEAC Environmental Education Digest" No. 3.

Drake J.E., Winner E., 2013, How Children Use Drawing to Regulate Their Emotions, „Cognition and Emotion" Vol. 27, Iss. 3.

Goldstein T.R., Tamir M., Winner E., 2013, Expressive Suppression and Acting Classes, „Psychology of Aesthetics, Creativity, and the Arts" Vol. 7, No. 2.

Gross J.J., 1999, Emotion Regulation: Past, Present, Future, "Cognition and Emotion" Vol. 13, Iss. 5.

Klein K., Boals A., 2001, Expressive writing can increase working memory capacity, "Journal of Experimental Psychology: General" Vol. 130, No. 3.

Larsen R.J., 2000, Toward a Science of Mood Regulation, „Psychological Inquiry” Vol. 11, No. 3. 
Marszał-Wiśniewska M., Fajkowska M., 2010, Właściwości psychometryczne Kwestionariusza Poznawczej Regulacji Emocji (Cognitive Emotion Regulation Questionnaire; CERQ) - wyniki badań na polskiej próbie, "Studia Psychologiczne" t. 49.

Myers D.G., 2000, The Funds, Friends, and Faith of Happy People, "American Psychologist” Vol. 55, No. 1.

Pennebaker J.W., 1997, Writing About Emotional Experiences as a Therapeutic Process, „Psychological Science" Vol. 8, Iss. 3.

Pennebaker J.W., Beall S.K., 1986, Confronting a Traumatic Event. Toward an Understanding of Inhibition and Disease, "Journal of Abnormal Psychology” Vol. 95, Iss. 3.

Pennebaker J.W., Francis M.E., 1996, Cognitive, Emotional, and Language Processes in Disclosure, "Cognition and Emotion" Vol. 10, Iss. 6.

Pennebaker J.W., Graybeal A., 2001, Patterns of Natural Language Use: Disclosure, Personality, and Social Integration, "Current Directions in Psychological Science” Vol. 10, No. 3.

Pennebaker J.W., O'Heeron R.C., 1984, Confiding in others and illness rate among spouses of suicide and accidental-death victims, "Journal of Abnormal Psychology" Vol. 93, Iss. 4.

Posłuszna J. (ed.), 2012, Psychology of Art and Creativity, Kraków: Aureus.

Ramirez G., Beilock S.L., 2011, Writing About Testing Worries Boosts Exam Performance in the Classroom, "Science” Vol. 331, Iss. 6014.

Shcherbatykh Y.V., 2000, Self-Regulation of Autonomic Homeostasis in Emotional Stress, „Human Physiology" Vol. 26, Iss. 5.

Smyth. J.M., Helm R., 2003, Focused expressive writing as self-help for stress and trauma, "Journal of Clinical Psychology" Vol. 59, Iss. 2.

Smyth J.M., Nazarian D., Arigo D., 2008, Expressive Writing in the Clinical Context [w:] I. Nykliček, A.J.J.M. Vingerhoets, M. Zeelenberg, Emotion Regulation: Conceptual and Clinical Issues, New York: Springer.

Soroko E., 2007, Regulacja emocji w kontekście rozwoju osobowości [w:] Serce i umyst, red. Ł. Kaczmarek, A. Słysz, Poznań: Wydawnictwo Naukowe UAM.

Sule A., Inkster B., 2014, A hip-hop state of mind, "The Lancet Psychiatry” Vol. 1, No. 7.

Van den Tol A.J.M., Edwards J., 2015, Listening to sad music in adverse situations: How music selection strategies relate to self-regulatory goals, listening effects, and mood enhancement, „Psychology of Music" Vol. 43, Iss. 4.

\section{Abstrakt}

Sztuka może pomagać radzić sobie z trudnymi doświadczeniami. Sesje arteterapii (leczenia poprzez sztukę) są znanym i skutecznym rodzajem terapii. Jednocześnie obserwuje się tendencje do - wydawać by się mogło - nieefektywnego dla dobrostanu (emocji, nastroju) angażowania się w tworzenie bądź kontakt ze sztuką (na przykład słuchanie smutnych piosenek, ekspresywne pisanie o trudnych przeżyciach). Wielu autorów opisywało, jak regulujemy negatywne emocje. Treści te nie wyczerpywały jednak tematu w odniesieniu do sztuki. W niniejszym artykule zaprezentowano proces regulacji emocji przez sztukę, zwłaszcza za pośrednictwem pisania ekspresywnego. Opisano również wpływ takiego sposobu regulacji na funkcjonowanie zadaniowe, szczególnie poznawcze.

\section{Słowa kluczowe}

psychologia twórczości, terapia sztuką, pisanie ekspresywne, regulacja emocji 


\section{Summary}

An Artist without Wings? Regulation of Emotions through Aesthetic Experiences

Art can help handle difficult experiences. Art therapy sessions (healing through art) have been recognized for years as a well-known and efficient method of treatment. In this paper is considered the problem of regulation of emotions through art, particularly through expressive writing. Important part of the paper is the impact of this way of regulation on task-oriented functioning, especially cognitive functioning.

Keywords

psychology of creativity, art therapy, expressive writing, regulation of emotions 